DOI: 10.38014/ehs-ss.2019.4.06

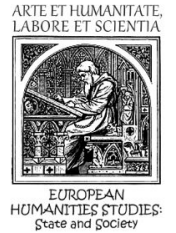

\title{
Tamila DZHAMAN
}

\section{Essence and the stages of the primary school teachers' preparation for the work in the conditions of inclusive education}

Humanization and continuity are the leading ideas of the development of modern education. According to the definition of International commission on education of the XXI century at UNESCO, continuous education has to unite all the activity and recourses in the educational sphere and direct them on the achievement of the harmonious development of the potential personal abilities and progress in the transformation of society [3].

Problems of general and professional students' training succession, various aspects of the functioning of the system continuous professional education are reflected in works of the leading Ukrainian scholars: $\mathrm{S}$. Goncharenko, R. Gurevych, I. Zazyun, G. Kostiuk, N. Nychkalo, V. Oliynyk, O. Savchenko, S. Sysoeva, L. Homych, M. Fitsulita, et al.

The analysis of the latest studies displays those investigations of V. Astahov, I. Vakarchuk, Y. Dragunov, G. Zinchenko, O. Kononenko, Y. Kuvshynov, I. Kuleshov, I. Latypov, L. Ohotnikov, I. Reutov, I. 
Samoyliukevych, L. Sgonik, O. Timets, I. Chelyshev, V. Shelud'ko, G. Yagodyn, et al. that are dedicated to the evaluation of continuous education.

However, today this problem needs further evaluation, especially referring to continuous training of future primary school teachers for professional activity in conditions of inclusive education.

Current scientific investigations are the ground of new theory and practice of the primary school teachers' preparation for the pedagogic activity in conditions of inclusive education.

In order to provide the development of continuous pedagogic education in Ukraine, a Conception of the development of continuous pedagogic education was elaborated that was approved by decree of Ministry of Education and Science of Ukraine № 1176 of August 14 2013. It is declared in the Conception that constant improvement of the system of training and advanced training of scientific-pedagogical and pedagogical workers is determined by the change of the human role in the modern world, by the vision of the ideal of individual's enlightenment and bringing up the new dictates to the quality of human investment accordingly to cultural and spiritual, social, economic and technologic transformations together with numerous challenges on global, European, national, regional and local levels.

The core principles of the development of continuous pedagogic education are defined in the Conception: openness and accessibility; continuity; a combination of national educational traditions and the best global experiences; flexibility in reaction on social changes and predictability; innovativeness.

According to the Conception, a goal of the development of continuous pedagogic education is the reproduction of the human investment and intellect of the society for the provision of constant human development of the country through a quality training of pedagogic personnel for the whole sphere of education; the creation of an effective system of training and advanced training of scientificpedagogical and pedagogical workers based on the combination of national achievements of world significance and stable European traditions of the provision of pedagogues' development who are capable to act professionally during the process of continuous improvement on the base of humanism, democracy, free competition and high technologies along with the assurance of continuous citizens' education accomplishing a practical realization of the educational policy as a function of the country of primary importance. 


\section{EUROPEAN HUMANITIES STUDIES: State and Society}

Nevertheless, training and advanced training of scientific-pedagogical and pedagogical workers is viewed as a significant ground that ensures the implementation of modernization of education on the base of comprehension of national and foreign experience.

A modern comprehensively developed personality, particularly a teacher, has to adequately, on a scientific basis, react on all challenges of time. While analyzing researches and publications of various authors and developers of a chain of official documents on the given problem we have to note that continuous education is the priority issue that appeared because of contemporary stages of scientific and technical development together with those social, economic and cultural changes that occur in our country.

It remains on the stage of a deep comprehension by philosophers, sociologists, and pedagogues. D. Enigin emphasizes that continuous education is a person's development as individuality during the life span together with a main systemic factor that forms the individuality comprising a goal and the final result of the process of constant and steadfast ascent to the new heights of perception and transformation of the world [2].

A system of continuous education is oriented on the integral human development as a personality, subject of operation and communication during the whole life. Continuous education is oriented on the proactive solution of problems regarding the development of society, science, industry; it must give every person the possibility to join the educational process on any stage of one's life.

In the context of these worldwide trends, the tasks of theoretical and methodological argumentation and estimation of the ways of development of continuous professional education have risen in Ukraine.

The idea of the necessity of studying throughout life that is transformed in the theory of "continuous education" is accepted globally.

The conception of continuous education became one of the key ideas at the turn of the XX-XXI centuries. The organization of continuous study appeared to be a subject of pedagogues' and psychologists' investigation from different countries. In the European countries, continuous education is not considered as a luxury but as an individual and national strategy of survival in the present highly competitive global economy. The governments of these countries perceive continuous education as one of the means of struggle with unemployment. 
However, the definition of continuous education is given vaguely which is linked with problems of the formation and development of the very system of continuous education. Only according to the materials of UNESCO it is used up to twenty various terms and conceptions regarding continuous education (for example, extended, permanent, renewed, compensatory, further, lifelong, education of adults, etc.).

Similarly, there is a notion of "renewed education" - education "in parts" during the lifespan, withdrawal of the practice of continuous study in a university that is separated from labor activity, the combination of education with other activities, particularly, professional. Moreover, the term "continuous education" is interpreted in many countries variously. Different terms are used in different countries - continuing - in England, remedial - in Sweden; in the USA is commonly used as a term "lifelong education, while in Ukraine - "continuous education" [4].

Two definitions are used for continuous education on the West: "continuing education" and "lifelong learning", thus, recently the last one is favored. These notions are not new; they are widely used for 40 years. They appeared in English in the twenties of the XX century for the first time and were associated with a tradition of adult education in the Nordic countries.

In the early sixties of the $X X$ century, these conceptions were introduced widely. The term "continuous education" appeared in the early eighties as the answer to the demands of the labor market. At that time a person was perceived as an "economic being", while education as the investments in human capital. Thus, the value of education decreased because it concentrated on human resources like capital and economic qualities as essential investments.

Regarding the definition "lifelong learning" that emerged in the sixties, it had the humanistic traditions from the very beginning. All humans are perceived as those who are capable of learning and the development of one's potential abilities at any age. From this perspective, the term appears to be an integral and means the age continuity of education. On the other hand, it can be viewed as idealistic as it is used in all possible cases making it suitable for any content. In the European practice "lifelong learning" is degrees and diplomas in spare time; professional courses, including further training; education for adults; second university education and so on.

In the encyclopedia, continuous education is perceived as a process that includes the whole life and that ensures the development of personal creative potential, comprehensive enrichment of one's spiritual 


\section{EUROPEAN HUMANITIES STUDIES: State and Society}

potential, purposeful regular cognitive activity concerning mastering and enhancement of knowledge, skills, and abilities gained in comprehensive, special institutions and by self-education. In other words, continuous education is a lifelong education in conditions of rapid transformation as mean of adaptation. The main stages of continuous education are person's teaching, education, and development that precede one's entry to independent life; educational activity during adulthood combined with various kinds of practical activity [3].

In the encyclopedia of professional education continuous education is explainedasanincreasing processof "educational(generaland professional) individual's potential over the life course that is organizationally provided by the system of governmental, social institutions and is appropriated to demands of an individual and society" [9].

In the Ukrainian pedagogic vocabulary, continuous education is defined as the totality of means, ways, and forms of obtaining an extension of general education, professional competence, culture, training, civil and moral maturity. For every person, continuous education is a process of formation and satisfaction of one's cognitive requests and spiritual needs, development of inclinations and abilities within a system of governmental and social educational institutions and by self-education [1].

L. Sigaeva perceives continuous professional education as a process directed on an individual's comprehensive development, systematic replenishment of knowledge during which improves a professional competence and enriches a person's spiritual necessity [8].

Continuity of education is sometimes formally interpreted as continuity of educational activity, its continuation after the completion of so-called basic education. According to the Ukrainian scholars (A. Alekseiuk, P. Volovyk, N. Nychkalo, S. Sysoeva), continuous education is linked to human cognition of self, one's interests, and abilities. It includes all the elements, beginning with preschool training, primary and secondary, higher, postgraduate education and informal study. I. Zazyun notes that the essence and goal of any education is Human in continuous (throughout life) development while the final result of education is the inner person's state on the level of necessity to perceive something new, gain knowledge, produce material and spiritual values, help neighbors [4].

Thus, continuous education is a purposeful acquisition and improvement of knowledge, skills, and abilities by a person throughout life; this is an integral process that provides a gradual development of a personality's creative potential. 
The substance of the term "continuous education" includes, at least, such components as the very educational system (formal and informal), all the educational measures that are accomplished after completion of formal education [8].

In other words, the essence of the principle of continuous education lies in the understanding of the educational system as a whole that includes all the links on different stages of human life starting from preschool to postgraduate education, profession or specialty change, advanced training, self-education, namely, the matter is inconsistent and interrelated process of human education over the life course. This correspondently strengthens the role of individual orientation in continuous education.

Hereby, the system of continuous education consists of various levels, which are interrelated under one goal - the obtainment of knowledge, skills, and experience by specialists of certain occupation that is reflected in the Ukrainian Act "About higher education" and in the statute of educational qualification levels.

The training on various levels anticipates the reception of knowledge, skills, and experience by future specialists of different professions including primary school teachers. Consequently, the problem of essential reformation of the higher education in a sphere of primary education emerges nowadays.

Analyzing the scholars' works, it can be mentioned that a system of continuous education is organized by the principle of an integral system that helps to develop a person's creative potential. It has basic and professional components that interact with each other and are directed on the training of active subjects of work, perception, and communication $[5 ; 6 ; 7 ; 8]$.

According to N. Protasova, the integral system of continuous education should be analyzed as [5]:

- concession of possibilities to every citizen to learn general and special disciplines according to social and individual needs;

- the totality of educational interrelated links that dynamically develop and provide succession in the study;

- way to the constant growth of a real intellectual qualification and spiritual potential of society.

In the National doctrine of the development of education, the Conception of continuous pedagogic education the ways of ensuring the development of pedagogic education are determined. 


\section{EUROPEAN HUMANITIES STUDIES: State and Society}

Hence, Ukraine clearly defined the orientation to the European educational and scientific spheres, realizes the modernization of educational activity according to the European demands, and persistently works on practical accession to the Bologna Process. However, the wellorganized system of advanced training and retraining in Ukraine become a thing of the past. The new system that would satisfy the needs of the market economy isn't created. Therefore, the essential European principle of "lifelong education" cannot be fully implemented in the conditions of our country.

Therefore, ensuring sustainable development and improvement of the system of higher education, its recognition in the European and global spaces in the context of quality assurance are the priority strategies of university education in Ukraine.

We consider that state policy of Ukraine regarding continuous education should be implemented according to world trends of lifelong education, social and economic, technologic, cultural changes together with the help of international projects and programs of collaboration.

Generally positive dynamics of continuous primary school teachers' training in Ukraine accepts the presence of problems that are prearranged by external factors and internal peculiarities of modern activity as well. First of all, they are the following:

- the decline of the prestige of pedagogic education, lowering of primary school teacher's social status;

- absence of the conception of professional continuous primary school teachers' training, its legal framework and economic mechanisms of its implementation;

- the incongruity of methodological approaches during the creation and realization of hereditable governmental educational standards and programs of all stages of continuous education, mechanisms of their monitoring;

- absence of theoretically proved approaches in scientific and methodological ensuring of continuous primary school teachers' training on various stages and standards of education.

- the disparity between theoretical and practical students' preparation.

It is essential to stress that grounds of the government policy are enshrined in the National Doctrine of development of education and National strategy of development of education in Ukraine for 2012-2021 and expect the realization of the succession of measures concerning 
reformation of the system of higher education in Ukraine in new social and economic conditions regarding the worldwide (civilizational) tendencies of the development of education. The improvement of the national system of higher education, its integration in global educational space views the formation of an effective model of governmental educational policy that is capable to provide the growth of quality of educational services; implementation of innovative pedagogic systems; equal access of all citizens to quality education, opportunities and freedom of choice in education; modernization of substance of education and its organization accordingly current global tendencies and demands of the labor market; providing continuous education and training over the life course, etc.

The analysis of scholar literature that was conducted gave us the possibility to clarify the term "continuous primary school teachers' preparation for work in the conditions of inclusive education".

Thus, under continuous primary school teachers' preparation for work in the conditions of inclusive education we understand the process aimed at a personality's full development, systematic replenishment, and improvement of knowledge, skills, and experience, the extension of professional competence that starts from learning in pedagogic university and proceeds throughout life.

Namely, continuous primary school teachers' preparation for work in conditions of inclusive education covers a system of primary school teachers' preparation in higher education institution and system of further pedagogic education.

Process of training of pedagogic staff envisages gradual acquirement of necessary competencies by subjects of education that gives them right to perform professionally in educational institutions and facilities connected with human education, training and development. Therefore, continuous education doesn't mean only education over the life course but also means permanent transit to higher levels, human quality and quantity progress in operating one's professional knowledge and skills, acquisition of living and professional experience.

The benchmarks of continuous teachers' training for work in the conditions of inclusive education of primary school pupils are the following:

- realization of tasks of continuous pedagogic education through variability and coordination of professional teacher's training in various institutional forms; 


\section{EUROPEAN HUMANITIES STUDIES: State and Society}

- surmounting of the existed narrow functional approach to professional pedagogic training for the formation of pedagogy's personality who is capable of constant self-improvement throughout the professional career;

- ensuring the balance between theoretical and practical components of professional training through increasing its practical direction on competence;

- development of the semantic core of pedagogic education on various levels of its obtaining;

- definition of perspective ways of teachers' professional development and further training.

The purpose-oriented role of continuous primary school teachers' preparation is ensuring the multistage, variable preparation of stuff, improvement of substance and means of its organization, surmounting of the linear approach to the organization of the professional pedagogic education. Logically continuous primary school teachers' preparation has a through character and implies a few stages basing on its purposes.

Therefore, in a structure of a system of continuous primary school teachers' preparation for work in the conditions of inclusive education we select the following stages (levels):

1. The primary-professional stage - professional training in a university (bachelor's degree).

2. The systematically-professional stage - the continuation of professional training in a university (master's degree).

3. Akme-professional stage - advanced training in a system of postgraduate pedagogic study, constant self-education.

It's essential to note that every stage is an independent stage of teacher's professional formation and development, has its purpose, proper meaning content and methodological ensuring. In this case, every stage/ level is a logical continuation of the previous one. The transition from one stage/level to the other means qualitative and quantitative improvement of professional competence and providing with primary school teacher's professional development.

Therefore, despite the positive dynamics of the development of continuous primary school teachers' preparation in Ukraine, there is still a problem of elaboration and theoretical argumentation of the system of continuous primary school teachers' preparation for work in the conditions of inclusive education is a promising avenue for our research. 


\section{References:}

1. Goncharenko, S. U. Ukrainian pedagogic dictionary (2 nd ed.) - Rivne: Charms of Volyn, 2011. - 552 p.

2. Enigin, D. V. Principles of the development pedagogic mastery of primary school teachers in the system of continuous education [Web source] / Enigin D. V. / Contemporary investigations and innovations. - October 2012. - № 10. - Retrieved from http://web.snauka.ru/issues/ 2012/10/18150 (21.02.2014)

3. Encyclopedia of education / Academy of pedagogic sciences of Ukraine. In Kremen', V. G. (Ed.) - Kyiv: Greencom Inter, 2008. - 1040 p.

4. Zazyun, I. A. Continuous education as a base of social onward / Zazun, I. A. // Continuous professional education: theory and practice: a collection of scientific works in 2 p. In Zazyun, I. A. \& Nychkalo N. G. (Eds.) - Kyiv, 2001. - P. 1. - pp. 15-23.

5. Protasova, N. G. Postgraduate teachers' education: content, structure, tendencies of development. - Kyiv: Lybid', 1998 - 122 p.

6. Savchenko, O. Y. Improvement of professional training of the future primary school teachers. - Primary school, 2005, - № 7. - pp. 1-4.

7. Semychenko, V.A. Psychological aspects of professional training and postgraduate education of pedagogic staff. // Postgraduate education in Ukraine. - 2001. - № 1. - pp. 54-57.

8. Sigaeva, L. E. Problem of teachers' preparation and advanced training in the context of continuous education // Pedagogy, and psychology. - 1999. - № 3. - pp. 94-100.

9. Encyclopedia of professional education: [in 3 vol.] In Batyshev, S. Y. (Ed.). Moscow: APO, 1998. - 568 p.

\section{Transliteration of References:}

1. Gonharenko C.U. (2011). Ukrainckyj pedagogihnyj clovnyk. Vydanya druge, dop.i vypr. Rivne : Volynski oberegy. 552 s. [in Ukrainian]

2. Enygin D.V. Zasady rozvytku pedagogihnoyi maysternosti vhyteliv pohatkovyx klasiv u systemi neperervnoyi osvity [elektronyj resurs]: http://web.snauka.ru/ issues/ 2012/10/18150 (21.02.2014).

3. Entsyklopedia osvity. Akad.ped.nauk Ukrainy / Gol.red.V.G.Kremenj. Kiev : Grinkom Inter, 2008. 1040 s.

4. Zyazyun I.A. (2001). Neperervna osvita yak osnova cotsialnogo postupu. Kiev : Grinkom inter. S.15-23. [in Ukrainian]

5. Protasova N.G. (1998). Pislyadyplomna osvita pedagogiv: zmist, struktura, tendentsiyi rozvytku. Kiev : Lybidj, 122 s. [in Ukrainian]

6. Savhenko O.Ya. (2005). Udoskonalennya profesijnoji pidgotovky majbutnix uhyteliv pohatkovyx klasiv. Pohatkova shkola, 7, 1-4.

7. Semyhenko V.A. (2001) . Psyxologihni aspekty profesijnoji pidgotovky i 


\section{EUROPEAN HUMANITIES STUDIES: State and Society}

pislyadyplomnoji osvity pedagogihnyx kadriv. Pislyadyplomna osvita v Ukraini, $1,54-57$.

8. Sigaeva L.E. (1999). Problema pidgotovky I pidvyshenia kvalifikatsyji vhyteliv $\mathrm{u}$ konteksti neperervnoji osvity [Problem of preparation and improvement of gualification of teachers in the context of continuous education]. Pedagogika i psychologiy, 3, 94-100.

9. Entsyklopedia profesijnoi osvity [v 3-x t.]. / Gol.red.S.Ya.Batyshev. Moskva : APO, 1998. 568 s. [in Rasha]

The Author

Tamila Jaman

Candidate of Pedagogical Sciences, Associate Professor, Head of the Cabinet of Educational Work

and Extracurricular Education,

Rivne Regional Institute

of Postgraduate Teacher Education,

Rivne, Ukraine

E-mail:jaman-tv@ukr.net

Abstracts

ДЖАМАН ТАМІЛА. Сутність і етапи неперервної підготовки вчителів початкової шкоди до роботи в умовах інкдюзивного навчання. У статті розглядається проблема неперервної підготовки вчителів початкової школи до роботи в умовах інклюзивного навчання. Проведено огляд наукових досліджень та уточнено сутність поняття «неперервна підготовка вчителів початкової щколи до роботи в умовах інклюзивного навчання». Виділено етапи неперервної підготовки вчителів початкової школи до роботи в умовах інклюзивного навчання: початково-професійний, системно-професійний та акме-професійний. Визначено основні проблеми неперервної підготовки вчителів початкової школи до роботи в умовах інклюзивного навчання, які потребують теоретичного обьрунтування і вирішення. Запропоновані цільові орієнтири неперервної підготовки вчителів початкової школи до роботи в умовах інклюзивного навчання.

Ключові слова: неперервна освіта, неперервна підготовка, професійна підготовка, учителі початкової школи, інклюзивне навчання. 
ДЖАМАН ТАМИЛА. Понятие и этапы непрерывной подготовки учителей начальной шкоды к работе в условиях инклюзивного образования. В статье рассматривается проблема непрерывной подготовки учителей начальной школьк к работе в условиях инклюзивного образования. Проведено обозрение научных исследований и уточнено понятие «непрерывная подготовка учителей начальной школь к работе в условиях инклюзивного образования». Вылелены этапь непрерьвной подготовки учителей начальной школьк к работе в условиях инклюзивного образования: начально-профессиональный, системно-профессиональный, акме-профессиональный. Определены основные проблемы непрерывной подготовки учителей начальной школьк каботе в условиях инклюзивного образования, которые нуждатотся в теоретическом обосновании и решении. Предложены иелевые ориентиры непрерывной подготовки учителей начальной школь к работе в условиях инклюзивного образования.

Ключевые слова: непрерывное образование, непрерывная подготовка, профессиональная подготовка, учителя начальной школь, инклюзивное образование.

JAMAN TAMILA. Essence and the stages of the primary school teachers' preparation for the work in the conditions of inclusive education. This article addresses the problem of continuous primary school teachers' preparation for the work in conditions of inclusive education. A review of scientific research was conducted and the essence of the concept "continuous primary school teachers' preparation for the work in the conditions of the inclusive education" was clarified. The stages of continuous primary school teachers' preparation to the work in the conditions of inclusive education was highlighted. They are: primaryprofessional, system-professional and acme-professional. The main problems of continuous primary school teachers preparation to the work in the conditions of inclusive education, that needs theoretical substantiation and solving was defined. Targets of the continuous primary school teachers' preparation for the work in the inclusive education conditions was proposed. Keywords: continuous education, continuous preparation, professional preparation, primary school teachers, inclusive education.

DŻAMAN TAMILA. Pojęcie i etapy ustawicznego ksztacenia nauczycieli szkół podstawowych do pracy w warunkach edukacji włączającej. Artykut omawia problem ustawicznego ksztacenia nauczycieli szkót podstawowych do pracy w edukacji właczajacej. Dokonano 


\section{EUROPEAN HUMANITIES STUDIES: State and Society}

przegladu badań naukowych i wyjaśniono pojęcie "ustawicznego ksztacenia nauczycieli szkót podstawowych do pracy w edukacji właczajacej". Etapy ustawicznego ksztacenia nauczycieli szkół podstawowych do pracy w środowisku edukacji właczajacej: podstawowy, systemowy, zaawansowany. Zidentyfikowano główne problemy zwiazane z ustawicznym ksztaceniem nauczycieli szkót podstawowych do pracy w środowisku edukacji właczajacej, które wymagaja teoretycznego uzasadnienia $i$ rozwiazania. Proponowane sa konkretne punkty orientacyjne dotyczace ustawicznego ksztacenia nauczycieli szkót podstawowych do pracy w edukacji właczajacej. Stowa kluczowe: ciagłe ksztacenie, przygotowanie ustawiczne, szkolenie zawodowe, nauczyciele szkót podstawowych, edukacja włązajaca. 